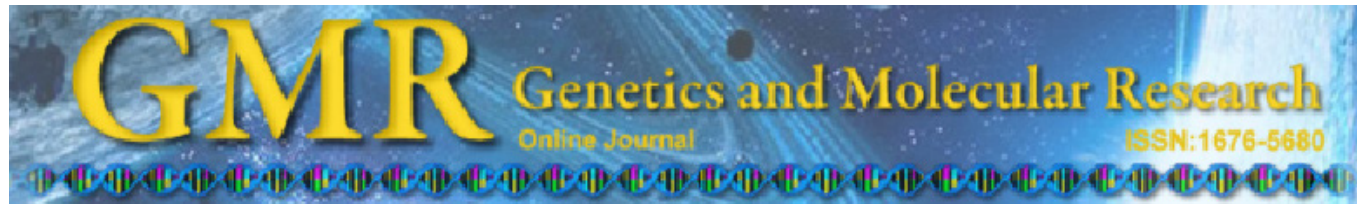

\title{
Isolation and characterization of 8 microsatellite loci from Chrysophyllum gonocarpum (Sapotaceae)
}

\author{
L.A. Rodrigues ${ }^{1}$, E.A. Ruas $^{2}$, N.C. Signori ${ }^{1}$, B.F. Costa ${ }^{1}$, \\ D.C.L. Farias-Missão ${ }^{2}$, B.G. Vieira ${ }^{2}$, A.R.O. Conson ${ }^{2}$, \\ C.L. Chaves ${ }^{2}$, J. Delfini ${ }^{1}$, C.F. Ruas ${ }^{2}$ and P.M. Ruas ${ }^{1,2}$ \\ ${ }^{1}$ Departamento de Agronomia, Centro de Ciências Agrárias, \\ Universidade Estadual de Londrina, Londrina, PR, Brasil \\ ${ }^{2}$ Departamento de Biologia Geral, Centro de Ciências Biológicas, \\ Universidade Estadual de Londrina, Londrina, PR, Brasil
}

Corresponding author: E.A. Ruas

E-mail: edu_wicca@yahoo.com.br

Genet. Mol. Res. 12 (1): 416-419 (2013)

Received May 17, 2012

Accepted October 15, 2012

Published February 8, 2013

DOI http://dx.doi.org/10.4238/2013.February.8.6

\begin{abstract}
Chrysophyllum gonocarpum is a tropical tree species that is very important in the recovery of heterogeneous forests and of degraded areas of permanent preservation. We identified microsatellite loci for $C$. gonocarpum to assess the genetic variability and the patterns of the population structure of the species. We isolated 8 microsatellite primers by using CT- and GT-enriched genomic libraries. We detected 2-4 alleles with 2.9 alleles per locus on average, by polymerase chain reaction. Test for cross-amplification showed that some loci were successfully amplified in 2 other Chrysophyllum species. The microsatellites can be used to assess the genetic diversity and population structure of $C$. gonocarpum. Some primer pairs can be amplified in $C$. marginatum and C. splendens.
\end{abstract}

Key words: Microsatellite isolation; Tree genetics; Cross-amplification; Codominant markers 


\section{INTRODUCTION}

Despite the importance of the high biological diversity found in Brazilian rainforests, information about the genetic diversity of trees is still scarce. In particular, less data are currently available to examine the hypotheses about the processes governing this diversity. The approach based on the characterization of spatial genetic diversity is extremely useful for addressing this issue. Chrysophyllum gonocarpum (Mart. and Eichl.) Engl. (Sapotaceae) is a semideciduous tree species that can grow up to $20 \mathrm{~m}$ in height and $1 \mathrm{~m}$ in diameter at chest height. This species is usually found in the States of Rio de Janeiro and Minas Gerais to Rio Grande do Sul, and its distribution extends to Uruguay, Argentina, and Paraguay (Reitz, 1968; Lorenzi, 2002). C. gonocarpum is a climax or late secondary species (Lorenzi, 2002) that has simple leaves with 1-6 flowers in the leaf axils, and its fruits are yellow drupes (Reitz, 1968) that are greatly appreciated by birds and small mammals. These characteristics make this species very important in the recovery of heterogeneous forests and the recovery of degraded areas of permanent preservation (Lorenzi, 2002).

Microsatellite markers are interesting in certain genetic studies because of their codominant nature, good reproducibility, and high polymorphisms (Litt and Luty, 1989). This study aimed to characterize 8 microsatellite loci from $C$. gonocarpum and observe their transferability to other species of the same genus.

\section{MATERIAL AND METHODS}

Genomic DNA of C. gonocarpum and 2 related species (C. marginatum and C. splendens) were extracted from the leaves using the cetyltrimethylammonium bromide (CTAB) method (Doyle and Doyle, 1987). An enriched microsatellite library was constructed using a hybridization-based capture method following the protocol described by Billotte et al. (1999) with the addition of biotin-labeled (CT) $)_{8}$ and $(\mathrm{GT})_{8}$ in the enrichment step. Microsatellite-rich fragments were amplified by polymerase chain reaction (PCR) using the Rsa21 adapter as a primer, cloned into the pGEM-T Easy vector (Promega, Madison, WI, USA), and transformed into Escherichia coli JM109 super-competent cells (Promega). The enriched library was screened for the presence of inserts by PCR using $10-\mu \mathrm{L}$ reaction mixtures containing $5.0 \mu \mathrm{L}$ GoTaq Green Master Mix (Promega), $1 \mu \mathrm{L} 10 \mathrm{pmol} \mathrm{Rsa2} 1$ adapter as primer, $2 \mu \mathrm{L}$ recombinant colonies, and $2 \mu \mathrm{L}$ sterile water. Amplifications were performed in a thermal cycler (PTC200; MJ Research, St. Bruno, Quebec, Canada) programmed with a hot start of 4 min at $95^{\circ} \mathrm{C}$ followed by 30 cycles of $94^{\circ} \mathrm{C}$ for $30 \mathrm{~s}, 52^{\circ} \mathrm{C}$ for $45 \mathrm{~s}$, and $72^{\circ} \mathrm{C}$ for $1 \mathrm{~min}$, and $30 \mathrm{~s}$ with a final extension at $72^{\circ} \mathrm{C}$ for $7 \mathrm{~min}$. Plasmids were isolated from 84 positive clones and sequenced in the ABI 3130XL Automated Sequencer (Applied Biosystems). Of the 84 sequenced inserts, 32 (38.09\%) clones contained microsatellites; however, only 10 of these proved suitable for primer design. Primers were designed using the PRIMER3 version 0.4.0 program (Rozen and Skaletsky, 2000), and the consistency of PCR amplification was tested using a sample of 5 individuals with each pair of primers. Amplifications were performed in a volume of $10 \mu \mathrm{L}$ containing $3.5 \mu \mathrm{L}$ GoTaq Green Master Mix (Promega), $0.25 \mu \mathrm{L} 5$ pmol forward and $0.25 \mu \mathrm{L}$ 5 pmol reverse primers (Table 1), and $2.0 \mu \mathrm{L} 10 \mathrm{ng}$ genomic DNA, and the final volume was adjusted using sterile water. PCR profiles consisted of an initial denaturation step of 4 min at $94^{\circ} \mathrm{C}$ followed by 16 touchdown cycles at $94^{\circ} \mathrm{C}$ for $30 \mathrm{~s}, 65^{\circ}-50^{\circ} \mathrm{C}\left(-1^{\circ} \mathrm{C} /\right.$ cycle $)$ for $30 \mathrm{~s}, 72^{\circ} \mathrm{C}$ 
for $1 \mathrm{~min}$ followed by 30 additional cycles at $94^{\circ} \mathrm{C}$ for $30 \mathrm{~s}, 50^{\circ} \mathrm{C}$ for $30 \mathrm{~s}$, and $72^{\circ} \mathrm{C}$ for $1 \mathrm{~min}$ with a final extension at $72^{\circ} \mathrm{C}$ for $7 \mathrm{~min}$ for Cgon 12 , Cgon 18 , and Cgon52 loci, and a locusspecific annealing temperature for the remaining 5 loci (Table 1). The amplification products were resolved on a $7.0 \%$ polyacrylamide gel and visualized after silver staining. Of the 10 primer pairs tested, 2 failed to yield satisfactory results, and 8 were selected for further analysis. For characterization of the 8 selected loci, we genotyped 48 individuals of $C$. gonocarpum, which included 3 populations from southern and southeastern Brazil. The samples consisted of 30 individuals of a single population from Rancho Alegre, Paraná State $\left(22^{\circ} 56^{\prime} \mathrm{S} 50^{\circ} 54^{\prime} \mathrm{W}\right.$; collection number, 0511); 9 samples from Araguari, Minas Gerais State $\left(18^{\circ} 29^{\prime} \mathrm{S} 48^{\circ} 23^{\prime} \mathrm{W}\right.$; collection number, 0211$)$, and 9 samples from Londrina, Paraná State $\left(23^{\circ} 31^{\prime} \mathrm{S} 51^{\circ} 16^{\prime} \mathrm{W}\right.$; collection number, 0111). Vouchers were deposited at the FUEL Herbarium at the Universidade Estadual de Londrina (Rancho Alegre: FUEL 30877 and Londrina: FUEL 30869).

\begin{tabular}{|c|c|c|c|c|}
\hline Locus name/GenBank ${ }^{\mathrm{a}}$ & Primer sequence $\left(5^{\prime}-3^{\prime}\right)$ & Repeat motif & Allele size (bp) & $\mathrm{Ta}\left({ }^{\circ} \mathrm{C}\right)$ \\
\hline Cgon12/JQ036324 & $\begin{array}{l}\text { F: CCCAACTCACACCATAGCAG } \\
\text { R: TGCGGACGAACAACTGTACT }\end{array}$ & $(\mathrm{AC})_{4}(\mathrm{CA})_{2}$ & $174-200$ & Touchdown \\
\hline Cgon18/JQ036325 & $\begin{array}{l}\text { F: GAAGGTGATCAACCCACTTGA } \\
\text { R: GCGTAGGACTGCAGAGTGTG }\end{array}$ & $(\mathrm{TA})_{4}$ & $190-220$ & Touchdown \\
\hline Cgon21/JQ036326 & $\begin{array}{l}\text { F: AGGAGAGCGAGAACCACAAA } \\
\text { R: GTTTAAAAGCGTCCCCCTTC }\end{array}$ & $(\mathrm{AG})_{9}$ & $180-220$ & 57 \\
\hline Cgon34/JQ036327 & $\begin{array}{l}\text { F: CACGCAAGTTTCAAATTCACA } \\
\text { R: TCCACATTATTTGGGCAGAA }\end{array}$ & $(\mathrm{GA})_{10} \mathrm{~A}(\mathrm{GA})$ & $170-220$ & 55 \\
\hline Cgon51/JQ036328 & $\begin{array}{l}\text { F: GAGTGAGAAACCCGCCACT } \\
\text { R: TGCACACCCAAGGACTTGTA }\end{array}$ & $(\mathrm{CA})_{5}$ & $158-210$ & 55 \\
\hline Cgon52/JQ036329 & $\begin{array}{l}\text { F: ACTTGGCAATCACTCGCTCT } \\
\text { R: ACACGCATTTCTCGCTCTCT }\end{array}$ & $(\mathrm{AG})_{4 \ldots}(\mathrm{AG})_{4}$ & $160-210$ & Touchdown \\
\hline Cgon57/JQ036330 & $\begin{array}{l}\text { F: CCAATCCAAAGCCTCTATGTG } \\
\text { R: ACAAATTTGATTGGCGTCGT }\end{array}$ & $(\mathrm{AC})_{9}$ & $209-230$ & 53 \\
\hline Cgon76/JQ036331 & $\begin{array}{l}\text { F: AGTTCACCAGGACGATGTGG } \\
\text { R: CATCCTCAAGCAGCATAGCA }\end{array}$ & $(\mathrm{TG})_{9}$ & $175-233$ & 53 \\
\hline
\end{tabular}

$\mathrm{Ta}=$ annealing temperature. ${ }^{\mathrm{a}} \mathrm{GenBank}$ accession number.

\section{RESULTS AND DISCUSSION}

The genotyping of $C$. gonocarpum and cross-amplification tests were performed under the same amplification conditions as those used for primer optimization. For characterization of the polymorphic loci, we used the Cervus version 2.0 software (Marshall et al., 1998). Deviations from Hardy-Weinberg equilibrium and linkage disequilibrium were determined using the Arlequin version 3.1 software (Excoffier et al., 2005). The genotyping of 48 individuals of $C$. gonocarpum showed moderate levels of polymorphism with 23 alleles. The number of alleles ranged from 2 (Cgon18, Cgon51, and Cgon57) to 4 (Cgon34 and Cgon76) with an average of 2.9 alleles per locus (Table 2).

The average polymorphic information content ranged from 0.02 to 0.53 , and the values of observed heterozygosity and expected heterozygosity varied from 0.02 to 0.75 and from 0.02 to 0.62 , respectively. One locus (Cgon21) deviated from the expectations of HardyWeinberg equilibrium (Table 2), while significant linkage disequilibrium $(\mathrm{P} \leq 0.05)$ was not observed in these loci. The cross-amplification tests included 3 individuals from each species, and we observed that the primers could be successfully transferred with some loci for $C$. 
marginatum (Cgon21, Cgon34, Cgon52, and Cgon57) and C. splendens (Cgon34, Cgon52, and Cgon57). These microsatellite loci can be effective tools for detecting the genetic structure of $C$. gonocarpum and thus will provide further information about this species of considerable ecological significance in one of the world's richest tropical biome.

\section{Table 2. Characterization of eight microsatellite loci genotyped in Chrysophyllum gonocarpum.}

\begin{tabular}{llllll}
\hline Loci & $\mathrm{K}$ & $\mathrm{N}$ & $H_{\mathrm{O}}$ & $H_{\mathrm{E}}$ & \multicolumn{1}{c}{ PIC } \\
\hline Cgon12 & 3 & 48 & 0.208 & 0.191 & 0.426 \\
Cgon18 & 2 & 48 & 0.521 & $0.527^{*}$ \\
Cgon21 & 3 & 48 & 0.75 & 0.50 \\
Cgon34 & 4 & 43 & 0.326 & 0.041 & 0.433 \\
Cgon51 & 2 & 48 & 0.042 & 0.414 & 0.46 \\
Cgon52 & 3 & 48 & 0.521 & 0.021 \\
Cgon57 & 2 & 41 & 0.021 & 0.619 & 0.363 \\
Cgon76 & 4 & 0.415 & 0.02 \\
\hline
\end{tabular}

$\mathrm{K}=$ number of alleles; $\mathrm{N}=$ number of individuals typed; $H_{\mathrm{O}}=$ observed heterozygosity; $H_{\mathrm{E}}=$ expected heterozygosity; $\mathrm{PIC}=$ polymorphic information content. ${ }^{*}$ Significant deviation from Hardy-Weinberg equilibrium $(\mathrm{P} \leq 0.001)$.

\section{ACKNOWLEDGMENTS}

Research supported by Conselho Nacional de Pesquisa e Desenvolvimento (CNPq) and Fundação Araucária. CAPES grant scholarships to students pursuing their masters and $\mathrm{PhD}$ and to Post-doctoral students.

\section{REFERENCES}

Billotte N, Lagoda PJR, Risterucci AM and Baurens FC (1999). Microsatellite-enriched libraries: applied methodology for the development of SSR markers in tropical crops. Fruits 54: 277-288.

Doyle JJ and Doyle JL (1987). A rapid DNA isolation for small quantities 161 of leaf tissue. Phytochem. Bull. 19: 11-15.

Excoffier L, Laval G and Schneider S (2005). Arlequin (version 3.0): An integrated software package for population genetics data analysis. Evol. Bioinform. Online 1: 47-50.

Litt M and Luty JA (1989). A hypervariable microsatellite revealed by in vitro amplification of a dinucleotide repeat within the cardiac muscle actin gene. Am. J. Hum. Genet. 44: 397-401.

Lorenzi H (2002). Árvores Brasileiras: Manual de Identificação e Cultivo de Plantas Arbóreas Nativas do Brasil. $2^{\mathrm{a}}$ ed. Plantarum, Nova Odessa.

Marshall TC, Slate J, Kruuk L and Pemberton JM (1998). Statistical confidence for likelihood-based paternity inference in natural populations. Mol. Ecol. 7: 639-655.

Reitz PR (1968). Sapotaceas. Itajaí: Herbário Barbosa Rodrigues, Flora Ilustrada Catarinense. Parte I: As Plantas. 72.

Rozen S and Skaletsky HJ (2000). PRIMER 3 on the WWW for General Users and for Biologist Programmers. In: Bioinformatics Methods and Protocols: Methods in Molecular Biology (Krawetz S and Misener S, eds.). Humana Press, Totowa, New Jersey. 